\title{
Analysis of $\mathrm{Bm} 86$ conserved epitopes: is a global vaccine against Cattle Tick Rhipicephalus microplus possible?
}

\author{
Análise de epítopos conservados da Bm86: é possível uma vacina global contra Carrapato-do-Boi \\ Rhipicephalus microplus? \\ Isabella Maiumi Zaidan Blecha ${ }^{1,2}$; Bárbara Guimarães Csordas ${ }^{1,3}$; André de Abreu Rangel Aguirre ${ }^{4}$; \\ Rodrigo Casquero Cunha ${ }^{5}$ Marcos Valério Garcia ${ }^{1,6}$; Renato Andreotti ${ }^{7 *}$ \\ ${ }^{1}$ Laboratório de Biologia do Carrapato, Embrapa Gado de Corte, Empresa Brasileira de Pesquisa Agropecuária - EMBRAPA, \\ Campo Grande, MS, Brasil \\ ${ }^{2}$ Programa de Pós-graduacão em Ciência Animal, Faculdade de Medicina Veterinária e Zootecnia - FAMEZ, \\ Universidade Federal de Mato Grosso do Sul - UFMS, Campo Grande, MS, Brasil \\ ${ }_{3}^{3}$ Programa de Pós-graduação em Doenças Infecciosas e Parasitárias, Universidade Federal de Mato Grosso do Sul - UFMS, \\ Campo Grande, MS, Brasil \\ ${ }^{4}$ Laboratório de Entomologia Médica, Fundação Oswaldo Cruz - FIOCRUZ, Porto Velho, RO, Brasil \\ ${ }^{5}$ Programa de Pós-graduação em Biotecnologia, Núcleo de Biotecnologia, Centro de Desenvolvimento Tecnológico - CDTec, \\ Universidade Federal de Pelotas - UFPel, Pelotas, RS, Brasil \\ ${ }^{6}$ Programa de Desenvolvimento Científico Regional - DCR, Fundação de Apoio ao Desenvolvimento do Ensino, Ciência e \\ Tecnologia - FUNDECT, Governo do Estado de Mato Grosso do Sul, Campo Grande, MS, Brasil \\ 7 Embrapa Gado de Corte, Empresa Brasileira de Pesquisa Agropecuária - EMBRAPA, Campo Grande, MS, Brasil
}

Received June 28, 2017

Accepted July 10, 2018

\begin{abstract}
The cattle tick Rhipicephalus microplus causes significant economic losses in agribusiness. Control of this tick is achieved mainly through the application of chemical acaricides, often resulting in contamination of animal food products and of the environment. Another major concern associated with acaricide use is the increasing reports of resistance of this tick vector against the active ingredients of many commercial products. An alternative control method is vaccination. However, the commercially available vaccine based on a protein homologous to $\mathrm{Bm} 86$ exhibits variations in efficacy relative to the different geographical locations. This study aimed to identify antigenic determinants of the sequences of proteins homologous to Bm86. Phylogenetic analyses were performed to determine the extent of divergence between different populations of $R$. microplus to identify the sequence that could be used as a universal vaccine against the multiple geographically distinct populations of $R$. microplus and related tick species. Considering the extensive sequence and functional polymorphism observed among strains of $R$. microplus from different geographical regions, we can conclude that it may be possible to achieve effective vaccination against these cattle ticks using a single universal Bm86-based antigen.
\end{abstract}

Keywords: Immuno-bioinformatics, phylogenetic analyses, Rhipicephalus microplus, ticks.

\section{Resumo}

O carrapato Rhipicephalus microplus é responsável por perdas significativas no agronegócio. O controle deste carrapato é feito principalmente por meio da aplicação de acaricidas químicos, geralmente resultando na contaminação de produtos de origem animal e do meio ambiente. Outra preocupação importante associada ao uso de acaricidas é o crescente aumento de relatos sobre a resistência deste carrapato a princípios ativos de vários produtos comerciais. Uma alternativa de controle é por meio de vacinaçáo. Porém, a vacina comercializada contendo proteína homóloga à Bm86, apresenta variaçóes de eficácia em relação às diferentes localizaçóes geográficas. Este estudo buscou identificar determinantes antigênicos das sequencias de proteínas homólogas a Bm86. As análises filogenéticas foram feitas para

\footnotetext{
*Corresponding author: Renato Andreotti. Laboratório de Biologia do Carrapato, Sanidade Animal, Embrapa Gado de Corte, Empresa Brasileira de Pesquisa Agropecuária - EMBRAPA, Avenida Rádio Maia, 830, Zona Rural, CEP 79106-550, Campo Grande, MS, Brasil. e-mail: renato.andreotti@embrapa.br
} 
determinar a extensão da divergência entre diferentes populaçóes de $R$. microplus com o objetivo de identificar a sequência que poderia ser usada como vacina universal contra as múltiplas populaçóes geograficamente distintas de $R$. microplus e espécies de carrapatos relacionados. Considerando-se a extensa sequência e o polimorfismo observados entre linhagens de $R$. microplus de diferentes regióes geográficas, podemos concluir que pode ser possível obter uma vacinação efetiva contra esses carrapatos bovinos utilizando um único antígeno universal baseado em $\mathrm{Bm} 86$.

Palavras-chave: Imuno Bioinformática, análise filogenética, Rhipicephalus microplus, carrapatos.

\section{Introduction}

The morpho taxonomy of Rhipicephalus microplus complex has been challenged in recent years, and until now, they are known as a complex composed of five taxa, namely $R$. australis, $R$. annulatus, $R$. microplus clade $A$ sensu, $R$. microplus clade $B$ sensu and $R$. microplus clade $C$ sensu (BURGER et al., 2014; LOW et al., 2015; CSORDAS et al., 2016). This complex causes significant economic losses to livestock. In Brazil alone, the potential damage caused by this species amounts to US $\$ 3.24$ billion per year (GRISI et al., 2014).

Control of these parasites is mainly achieved through the use of acaricides. However, the pressure of use has genetically selected tick populations resistant to these products, resulting in serious problems such as a shortage of new acaricidal chemical entities and the accumulation of residues in both the environment and products of animal origin (ANDREOTTI et al., 2011; RECK et al., 2014; SINGH et al. 2015). Therefore, the search for alternative control methods has become increasingly necessary.

Tick control through vaccines is an alternative to the use of acaricides. Some examples of vaccines that use the Bm86 protein as an immunogen against ticks include TickGard ${ }^{\text {PLUS }}$ (formerly, Intervet Australia) (WILLADSEN et al., 1995) which is no longer commercially available and Gavac ${ }^{\mathrm{TM}}$ (Heber Biotec) (CANALES et al., 1997) which is the only one still available and, more recently, Bovimune Ixovac, Mexico (BOVIMUNE IXOVAC, 2018).

To understand why many vaccine strains should be tested, a better understanding of the history of the cattle tick $R$. microplus is necessary. Based on the history of the dissemination of $R$. microplus according to Barré \& Uilenberg (2010), R. microplus originated in the southern and southeastern regions of Asia and was thus regarded as one of the most successful invasive tick species, colonizing wide areas in Central and South America, South East Asia, Australia, and islands in the Pacific Ocean.

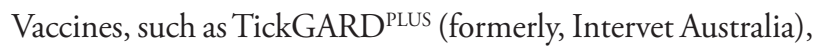
against the cattle tick in Australia, which was previously named $R$. microplus until it was morphologically and genetically distinguished from Rhipicephalus australis and now is part of the $R$. microplus complex (LABRUNA et al., 2009; ESTRADA-PEÑA, et al. 2012; LOW et al., 2015; CSORDAS et al., 2016) are effective against susceptible strains of Australian origin. Numerous tests have been performed and might exhibit a different pattern of sensitivity and therefore induce poorer control when applied against $R$. microplus in America (SUTHERST \& BOURNE, 2009).

Bm86-derived vaccines cause reduced weight of engorged adult female ticks, reduced egg mass weight, reduced numbers of ticks in the field over one generation, a decrease in the reproductive capacity of $R$. microplus females, decreased frequency of treatments with acaricides, and a positive impact on the implementation of integrated control programs (JONSSON et al., 2000; ODONGO et al., 2007; VARGAS et al., 2010). The TickGARD ${ }^{\text {PLUS }}$ (formerly, Intervet Australia) and Gavac ${ }^{\mathrm{TM}}$ (Heber Biotec) vaccines were shown to be $46.9 \%$ and $49.2 \%$ effective, respectively, against a Brazilian $R$. microplus strain (ANDREOTTI, 2006). This effectiveness is lower than that reported globally for other strains (RAND et al., 1989; RICHARDSON et al., 1993; PATARROYO et al., 2002). Bm86 from the Campo Grande strain (GenBank: ACA57829) collected from cattle under field conditions in Campo Grande municipality, Brazil, exhibits differences in hydrophobic regions compared with the vaccine proteins. These differences may contribute to the binding of antibodies to the target protein, which may explain the variation in efficacy in other regions worldwide (ANDREOTTI et al., 2008).

Humoral and cellular immune responses are important to an organism to react against specific regions of pathogens via a process known as the adaptive response. Vaccines based on subunits or synthetic peptides, which is a strategy that focuses on epitopes recognized by $\mathrm{B}$ and $\mathrm{T}$ cells and the major histocompatibility complex (MHC), that could elicit a specific immune response have been studied in recent decades (BEN-YEDIDIA \& ARNON, 1997). In silico epitope prediction tools are necessary to evaluate which regions of such proteins of interest could be candidates for a peptide-based vaccine. Initially, the predictions focused on epitopes that bind on MHC class I molecules for the development of cellular immune response against virus-infected cells and cancer (KAST et al., 1991; TOES et al., 1996). Examples of some classes of methods used in predictions are quadratic programming, linear programming and the use of sequence profiles obtained by clustering known epitopes of a given MHC allele to score candidate peptides (FLOREA et al., 2003).

The interaction of innate and acquired immune responses to ticks is what will determine the success of the host or the parasite. The innate response consists of an inflammatory reaction and a hemostatic process, such as vasoconstriction, clot activation and platelet aggregation (SZABÓ, 2008). Hypersensitivity related to histamine release by mast cells is noted in resistant animals (RIEK, 1962). Resistant animals exhibit increased cell infiltrate in the tick attachment site, which suggests that cellular immune response is important to confer natural resistance to the host (SZABÓ \& BECHARA, 1999).

Studies on peptide-based vaccines against ticks have been performed in the last decade. In silico analysis of $\mathrm{Bm} 86$ gut glycoprotein revealed that it contains antigenic epitopes, one of which has elicited greater than $80 \%$ efficacy in immunized cattle, against $R$. microplus (PATARROYO et al., 2002). Monoclonal antibodies against a peptide designed based on B cell epitopes from Bd86 (a Bm86 ortholog from Rhipicephalus decoloratus) 
could bind to gut cells from several Rhipicephalus species (including $R$. microplus) (KOPP et al., 2009). Reverse vaccinology approaches to identify new tick antigens are currently under investigation. However, the number of tick genome databases available is limited given that these parasites are eukaryotes and have a large genome (LEW-TABOR \& RODRIGUEZ-VALLE, 2016).

The post-genomic era revolution has produced massive sequence data on genomes, transcriptomes and proteomes, including those of $R$. microplus (BARRERO et al., 2017). This study aimed to identify antigenic determinants of the sequences of proteins homologous to $\mathrm{Bm} 86$ that could be used as a universal vaccine against the multiple geographically distinct populations of $R$. microplus. Variations in the Bm86 locus sequence have been reported in the literature (RODRÍGUEZ et al., 1994; COBON et al., 1995; GARCÍA-GARCÍA et al., 1999). This study aimed to determine the effect of sequence variability within the Bm86 locus on the major epitopes of the $\mathrm{Bm} 86$ protein as a means of identifying possible isolates that confer protection against $R$. microplus strains of various geographic origins.

\section{Materials and Methods}

\section{In silico analyses for epitope predictions}

For the analyses, we used tools based on the major histocompatibility complexes (MHCs) of cattle (bovine leukocyte antigen (BoLA)) and mice ( $\mathrm{H}-2$ antigen). Mouse $\mathrm{MHC}$ class I and II predictions are exclusively based on mouse $\mathrm{H}-2$ antigen because it is an animal model commonly used to screen candidate antigens before testing in cattle (AGUIRRE et al., 2016; CONTRERAS et al., 2016; LEW-TABOR \& RODRIGUEZ-VALLE, 2016). A variety of algorithms were run to generate a combination of results capable of predicting qualities that altered the statistical probability of a peptide sequence having antigenic potential for the host immune system in question (bovine MHC I via BoLA loci and mouse MHC I and II via the H-2 locus). We used the following prediction parameters to predict three major epitopes based on the Brazilian Bm86-CG (ACA57829) amino acid sequences published in GenBank: cattle MHC class I binding epitopes for the BoLA-AW10, BoLA-N:00101 and BoLA-D18.4 alleles (IEDB, 2018a); binding to the mouse MHC I H-2-Qa1, H-2-Dd and $\mathrm{H}$-2-Ld alleles (IEDB, 2018a); binding to the mouse MHC class II H-2-IAb and H-2-IAd alleles (IEDB, 2018b); linear epitopes for B lymphocytes (IEDB, 2018c); epitopes exposed on the protein surface in the tertiary structure (IEDB, 2018d); prediction of transmembrane helices (DTU bioinformatics, 2018a); prediction of intrinsically disordered protein regions (IUPRED2A, 2018); prediction of the signal peptide (DTU bioinformatics, 2018b); and prediction of glycophosphatidylinositol (GPI) anchors (PIERLEONI et al., 2008).

The function of each in silico tool mentioned above was to predict $\mathrm{Bm} 86$ regions with the potential to trigger cellular immune responses in cattle (the only available source for predictive tools for several animal species, netMHCpan, is based on MHC class I); predict regions with the potential to trigger cellular and humoral immune responses in mice (MHC class I was evaluated for comparison with cattle results) (VORDERMEIER et al., 2003; NENE et al., 2012; RODRIGUEZ-VALLE et al., 2013; AGUIRRE et al., 2016); predict B lymphocyte epitopes to ensure immunological memory and generate rapid antibody responses in immunized hosts exposed to the tick to avoid selecting epitopes in transmembrane helices, as these structures can mask epitopes because they are anchored to the cell membrane; evaluate intrinsically disordered regions, which are of some interest because they do not have a constant tertiary structure and the epitope is more likely to be exposed to the immune system when it is located in a flexible region of the protein, to avoid epitopes located in signal peptides, which are typically cleaved after the protein reaches its final destination; and predict glycophosphatidylinositol anchors (GPI) that may increase triggering of immune responses in the host.

To determine whether the epitopes predicted with the algorithms listed above are conserved among the different $\mathrm{Bm} 86$ sequences deposited in GenBank, all sequences were analyzed using the Mega 6.0 program (TAMURA et al., 2013), and an alignment was constructed using Gonnet modeling.

Protein BLAST (NCBI, 2018) was used to perform alignments of the epitopes predicted with Bos taurus protein sequences available in the SwissProt database using the BLASTP 2.5.1 program. This analysis aimed to ensure that the predicted sequences did not have homologies with host proteins, thereby minimizing autoimmune responses following vaccination.

\section{Sequence alignment and phylogenetic tree construction}

The Bm86-CG protein sequence (GenBank: ACA57829) and the three predicted epitope sequences were aligned with the sequences available from GenBank using the BLASTp program. In this way, a database was constructed that contained all similar sequences obtained from the analysis. The Mega 6.0 program (TAMURA et al., 2013) was applied to align the sequences taken from GenBank using the Gonnet protein weight matrix.

A Bayesian phylogenetic analysis was performed using the MrBayes 3.2.6 program (RONQUIST \& HUELSENBECK, 2003). An amino acid analysis was performed using the Dayhoff model (DAYHOFF et al., 1978). For the data set used in this study, approximately 500,000 generations were found to be sufficient for topology and were plotted using the FigTree 1.4.2 program (TREE BIO, 2016). All analyses for Bm86 epitopes and partial protein of $\mathrm{Bm} 86$ were initiated with random starting trees and were run for $1 \mathrm{X}^{1} 0^{6}$ generations, with trees being sampled every 1,000 generations. To determine the stationarity of the Markov chain, the log-likelihood scores of sample points were plotted against generation time. The first $25 \%$ of samples was estimated as burn-in for each data set. The remaining samples were retained for generating consensus trees. Each sample included a tree topology that incorporates branch length and substitution model parameter values. These topologies were used to generate a 50\% majority rule consensus tree, with the percentage of sample recovering any particular clade representing the posterior probability of a clade $(1=100 \%)$. No manual editing of the trees was performed. The clades of $R$. microplus - THAILAND (KAEWMONGKOL et al., 2015), R. appendiculatus (NIJHOF et al., 2009; KAMAU et al., 2011, 2016), 
$R$. decoloratus (ODONGO et al., 2007, CANALES et al., 2008), were collapsed (tree's triangle). Species of the tick Hyalomma detritum (AEK31101), H. detritum (AEK31102), H. anatolicum (ACD14076) were used as outgroups in phylogenetic analyses.

\section{Results}

The bioinformatics analysis predicted three major relatively conserved regions (Figure 1) in the $\mathrm{Bm} 86$ sequences from different geographical regions. The Bm86-CG protein sequence (GenBank: ACA57829) was used as a reference because it originated from a strain of $R$. microplus from the study region (ANDREOTTI et al., 2008).
The established mouse MHC class II and B cell epitopes were as follows: epitope 1 - SSGQRCVMENGNAVCKEKSDATT (23 amino acids, located between residues 566 and 588); epitope 2 - KCPDDHECSREPAKDSCSEEDNGK (24 amino acids, located between residues 540 and 563); and epitope 3 - DSYCSPGSPKGPDGQCKNAC (20 amino acids, located between residues 170 and 189) (Figure 1).

Epitope 1 (Figure 2) formed a distinct clade with high convergence for $R$. microplus populations from the geographical regions of Brazil, the United States and Mozambique, Israel and some populations from Thailand. A collapsed group was formed that included the variants from Thailand. Immediately below was formed with branch with variants from Thailand,


Figure 1. Analysis of Bm86-CG integration using free algorithms available online, based on T and B cell epitope predictions. Each tool predicts a certain characteristic based on calculations that use the properties of each amino acid in the primary protein sequence to generate graphs indicating which regions of the primary structure have a statistically significant probability of having the desired characteristic. For this purpose, a threshold (horizontal line parallel to the x-axis) is plotted. All regions of the graph that exceed this threshold are considered in the present analysis. By superimposing the graphs from different algorithms, we can better visualize which regions share the largest combination of antigenic characteristics. 


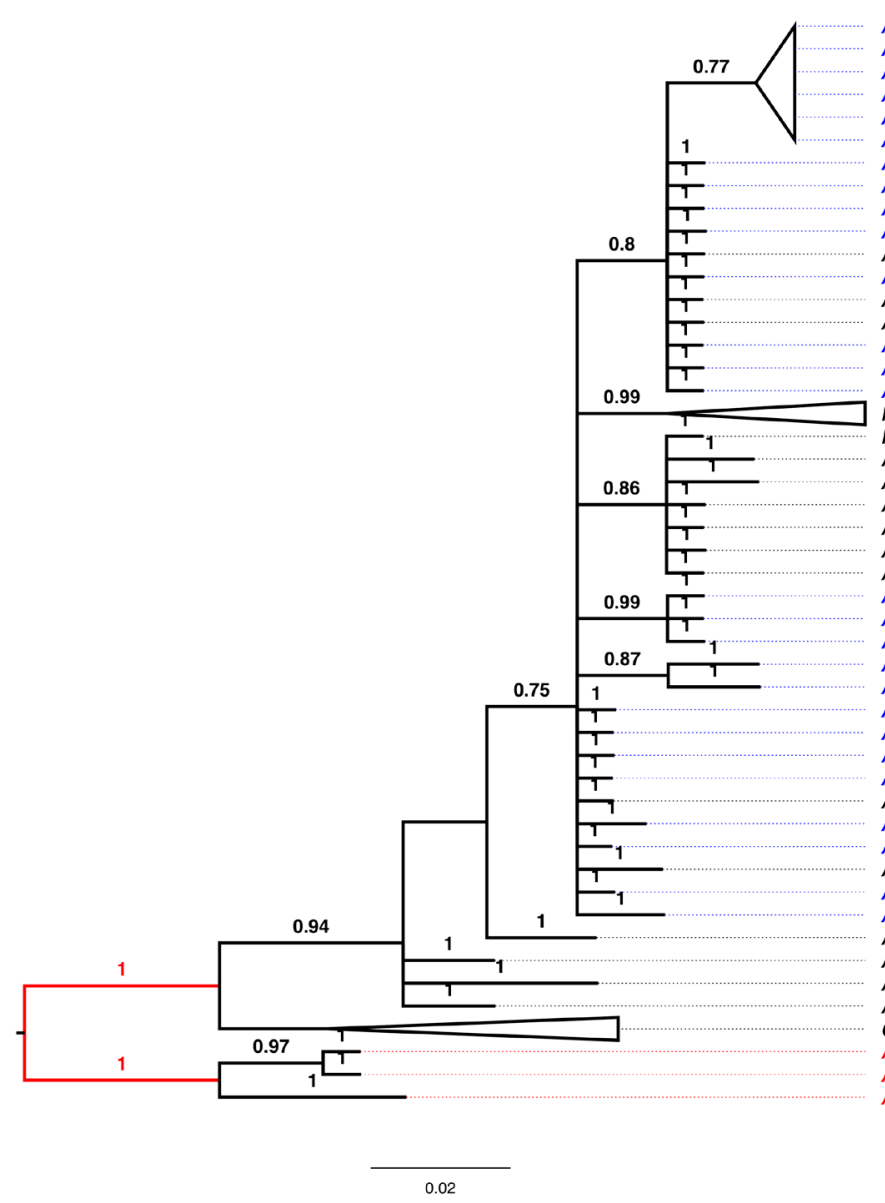

ACA57829 R. microplus - BRAZIL (Andreotti et al., 2008)

ADQ19677 R. microplus - USA (Freeman et al., 2010)

ADQ19690 R. microplus - USA (Freeman et al., 2010)

ADQ19688 R. microplus - USA (Freeman et al., 2010)

ACZ55133 R. microplus - MOZAMBIQUE (Nijhof et al., 2009)

ABY58968 R. microplus - MOZAMBIQUE (Canales et al., 2008)

ADQ19684 R. microplus - USA (Freeman et al., 2010)

ADQ19683 R. microplus - USA (Freeman et al., 2010)

ADQ19685 R. microplus - USA (Freeman et al., 2010)

ADQ19686 R. microplus - USA (Freeman et al., 2010)

ABY58969 R. annulatus - ISRAEL (Canales et al., 2008)

ADQ19687 R. microplus - USA (Freeman et al., 2010)

ADQ19691 R. annulatus - USA (Freeman et al., 2010)

ADQ19693 R. annulatus - USA (Freeman et al., 2010)

AJE29928 R. microplus - THAILAND (Kaewmongkol et al., 2015)

AJE29943 R. microplus - THAILAND (Kaewmongkol et al., 2015)

AJE29938 R. microplus - THAILAND (Kaewmongkol et al., 2015)

R. microplus - THAILAND (15 sequences) (Kaewmongkol et al., 2015)

P20736 R. australis (Willadsen et al., 1989)

ATW75471 R. australis - NEW CALEDONIA (Hüe et al. 2017)

ATW75472 R. australis - NEW CALEDONIA (Hüe et al. 2017)

ATW75473 R. australis - NEW CALEDONIA (Hüe et al. 2017)

ATW75474 R. australis - NEW CALEDONIA (Hüe et al. 2017)

ATW75475 R. australis - NEW CALEDONIA (Hüe et al. 2017)

ATW75476 R. australis - NEW CALEDONIA (Hüe et al. 2017)

AJE29958 R. microplus - THAILAND (Kaewmongkol et al., 2015)

AJE29926 R. microplus - THAILAND (Kaewmongkol et al., 2015)

AJE29927 R. microplus - THAILAND (Kaewmongkol et al., 2015) AJE29932 R. microplus - THAILAND (Kaewmongkol et al., 2015) AJE29930 R. microplus - THAILAND (Kaewmongkol et al., 2015) ADQ19680 R. microplus - USA (Freeman et al., 2010)

ADQ19689 R. microplus - USA (Freeman et al., 2010)

ACR19243 R. microplus - MEXICO (Canales et al., 2009)

AJE29931 R. microplus - THAILAND (Kaewmongkol et al., 2015) ACR19242 R. annulatus - USA (Canales et al., 2009)

AJE29929 R. microplus - THAILAND (Kaewmongkol et al., 2015) AJE29942 R. microplus - THAILAND (Kaewmongkol et al., 2015) ACL27210 R. annulatus - EGYPT (Shahein et al., 2008) AJE29924 R. microplus - THAILAND (Kaewmongkol et al., 2015) AJE29941 R. microplus - THAILAND (Kaewmongkol et al., 2015) ADR01312 R. evertsi - SOUTH AFRICA (Nijhof et al., 2010) ABG21130 R. decoloratus (Odongo et al., 2007) ABG21131 R. decoloratus (Odongo et al., 2007) ABY58970 R. decoloratus - SOUTH AFRICA (Canales et al., 2008) Clade R. appendiculatus (42 sequences) (Nijhof et al., 2009; Kamau et al., 2011; Kamau et al., 2016) AEK31101 Hyalomma detritum - TUNISIA (Nijhof et al., 2012)

AEK31102 Hyalomma detritum - TUNISIA (Said et al., 2012)

ACD14076 Hyalomma anatolicum - INDIA (Jeyabal et al., 2010)

Figure 2. Bayesian phylogenetic tree for epitope 1 (SSGQRCVMENGNAVCKEKSDATT) of protein Bm86-CG with 23 amino acids. The strains of Rhipicephalus microplus is shown in blue. The clade shown in red includes Hyalomma detritum and Hyalomma anatolicum (GenBank: AEK21101-102, ACD14076) and was used as an external group.

USA, Mexico, Egypt and the species Rhipicephalus annulatus (GenBank: ACR19242 and ACL27210). The other clades were separated by species divergent for epitope 1 .

For epitope 2 (Figure 3), the phylogenetic tree presented a clade with high convergence for $R$. microplus populations from the geographic regions of USA (FREEMAN et al., 2010), Mexico (CANALES et al., 2009), Israel (CANALES et al., 2009), and variants of Thailand (KAEWMONGKOL et al., 2015). High convergence with the $R$. annulatus species and $R$. decoloratus were observed in this same clade. The other clades were separated by species divergent for epitope 2 .

For epitope 3 (Figure 4), a large clade with high convergence was formed for all of the Brazilian $R$. microplus populations reported by Sossai et al. (2005) together with the Brazilian strain reported by Andreotti et al. (2008). In the same clade, high convergence was observed for the geographic regions of the United States (FREEMAN et al., 2010) and Mexico (CANALES et al., 2009), for all of variants $R$. microplus from Thailand (KAEWMONGKOL et al., 2015). High convergence for orthologous species $R$. annulatus (ABY58969) and $R$. decoloratus (ABY58970, ABG21130, ABG21131).

The $R$. annulatus species from Freeman et al. (2010) was located outside the large clade, revealing the average convergence for epitope 3. A distinct clade was formed for $R$. appendiculatus, and this clade exhibited divergence among the other species.

For the Bm86-CG protein (Figure 5), high convergence of Brazilian populations of $R$. microplus with other geographic regions including: USA United States (FREEMAN et al., 2010), Mexico (CANALES et al., 2009), Venezuela, Colombia, Uruguay and Argentina (SOSSAI et al., 2005), Mozambique (CANALES et al., 2008; NIJHOF et al.; 2009) and some variants from Thailand (KAEWMONGKOL et al., 2015).

Other clade was formed for the variants from Thailand (KAEWMONGKOL et al., 2015), the United States (FREEMAN et al., 2010) and the orthologous $R$. annulatus species (GenBank: ADR19242, ADQ19693, ADQ19691 and ACL27210). The other clades were separated by species that showed divergence of the Bm86 protein.

\section{Discussion}

According to De Groot (2006), a vaccine must promote and trigger a strong $\mathrm{B}$ cell and/or T cell response to be effective. Because complex cellular interactions occur during the development of an immune response, mapping and characterization of epitopes is of 

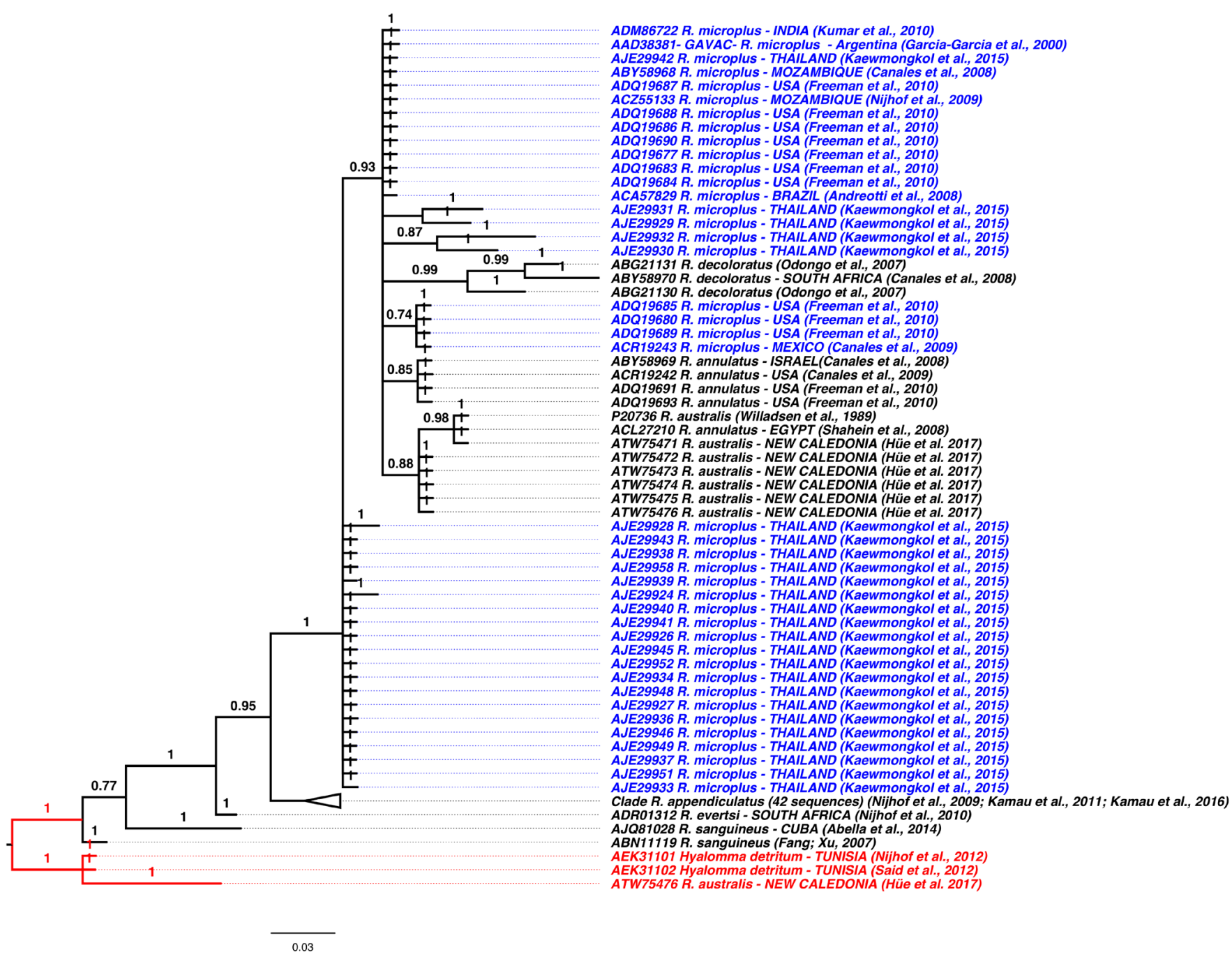

Figure 3. Bayesian phylogenetic tree for epitope 2 (KCPDDHECSREPAKDSCSEEDNGK) of protein Bm86-CG with 24 amino acids. The strains of Rhipicephalus microplus, is shown in blue. The clade shown in red includes Hyalomma detritum and Hyalomma anatolicum (GenBank: AEK21101-102, ACD14076) and was used as an external group.

fundamental importance for the selection of peptides with potent antigenicity as candidate vaccine components. The MHC genes of cattle were mapped from bovine autosome 23 (BTA 23) (FRIES et al., 1986; FRIES et al., 1993) and are referred to together as bovine leukocyte antigen (BoLA). This organization distinguishes BoLA from the MHC in humans and rodents, in which the MHC genes are located on chromosome 6 (HLA) and 17 (H-2), respectively (LEWIN, 1996). McShane et al. (2001) used FISH for mapping genes and revealed that tumor necrosis factor a (TNF- $\alpha$ ), heat shock protein 70 (HSP70.1) and 21 steroid dehydrogenase (CYP21) are closely linked in the region of BTA23 band 22 along with BoLA class I genes. Therefore, this gene is important for immunological functions.

Few variations that might be involved in the process associated with the global variability in vaccine efficacy were observed in the three Bm86-CG epitopes that were predicted here to be the most antigenic. In fact that, these epitopes contained regions with major similarities to homologous domains of Bm86 from strains from different geographical regions (RAND et al., 1989;
RICHARDSON et al., 1993; DE LA FUENTE et al., 1999; PATARROYO et al., 2002; ANDREOTTI, 2006; ANDREOTTI et al., 2008). Nevertheless, the variability observed in the Bm 86 molecule may explain the differences in the efficacy observed when cattle vaccinated with $\mathrm{rBm} 86-\mathrm{CG}$ and $\mathrm{rBm} 86$ were challenged by infesting with the same strain, $R$. microplus Campo Grande (CUNHA et al., 2012; ANDREOTTI, 2006).

Peconick et al. (2008) studied polymorphisms and observed that vaccine efficacy was not decreased despite changes in the amino acid sequences of polypeptide SBm7462 in two Brazilian isolates compared with the sequence of the polypeptide obtained from other isolates by Patarroyo et al. (2002). Despite the variability of proteins homologous to $\mathrm{Bm} 86$ and their impact on the immune response, it must be borne in mind that the genes of two $\mathrm{MHC}$ class II alleles of cattle have been described with a deletion of three base pairs in their nucleotide sequences, leading to the deletion of a lysine at the antigen recognition site. This deletion was correlated with increased immune response against the commercial vaccine TickGARD $^{\text {PLUS }}$ (formerly, Intervet Australia) (SITTE et al., 2002). 

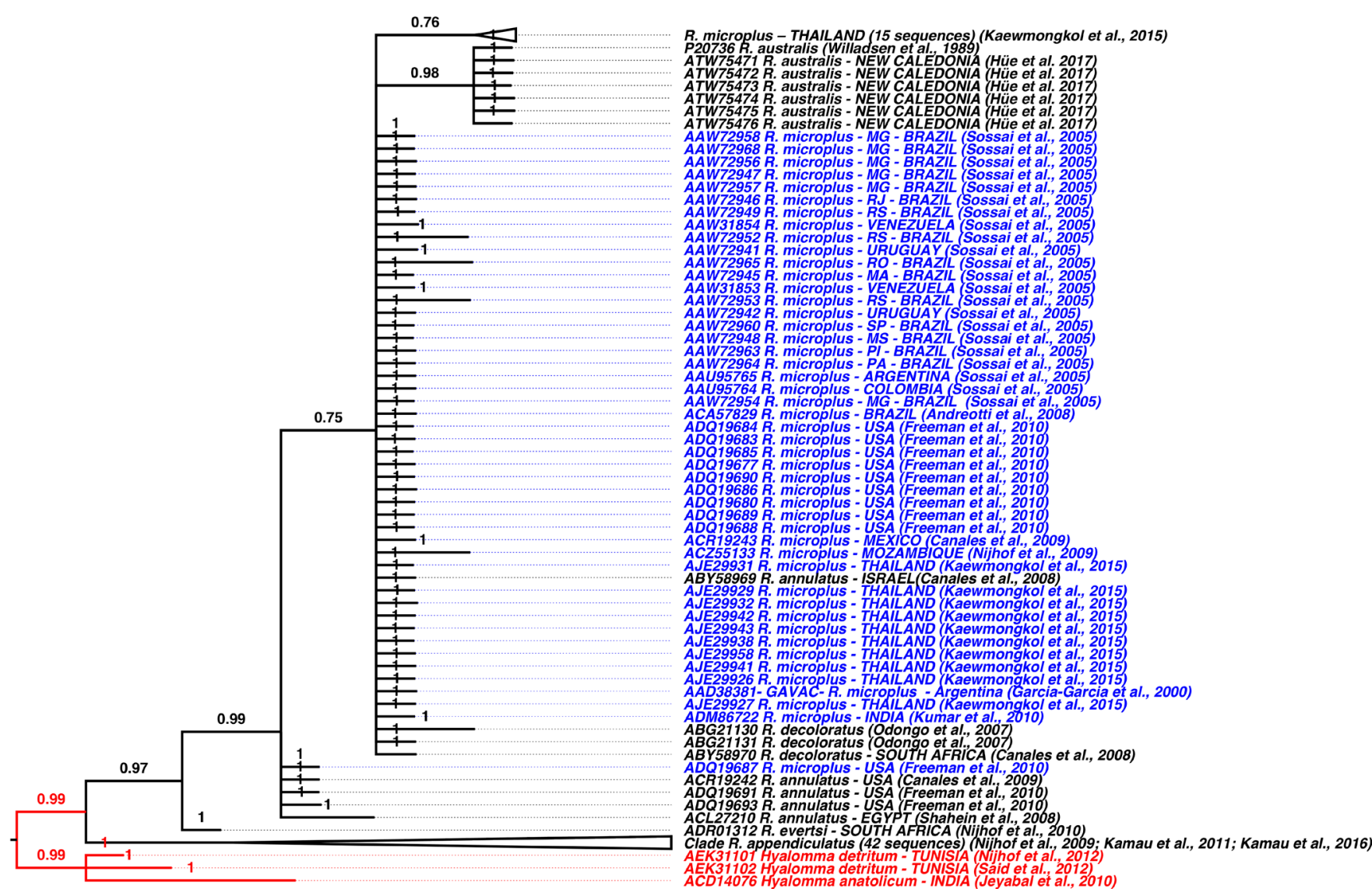

0.01

Figure 4. Bayesian phylogenetic tree for epitope 3 (DSYCSPGSPKGPDGQCKNAC) of protein Bm86-CG with 20 amino acids. Populations of Rhipicephalus microplus are shown in blue. The clade shown in red includes Hyalomma detritum and Hyalomma anatolicum (GenBank: AEK21101-102, ACD14076) and was used as an external group.

Thus, the influence of the genetic variation of the MCH class II alleles on the cattle immune response against vaccine antigens is also evident.

The criterion established based on the prediction of B lymphocytebinding linear epitopes had the objective of selecting sequences against which the host could trigger a humoral response in the shortest time following re-exposure to the antigen and that could be used to stimulate immune memory with boosters using vaccine antigen formulations. Were predicted $\mathrm{Bm} 86$ regions exposed on the surface of the tertiary structure as a basis for selecting peptide sequences accessible for binding to antibodies produced by the host against each peptide.

Predictions of transmembrane helices were used to define the regions that should be avoided. These regions are usually located next to the lipid bilayer of the cell membrane, hindering their access by host antibodies. Bm86-CG lacks transmembrane helices according to the results of our TMHMM analysis (data not shown). The prediction of intrinsically disordered regions was performed to select peptide sequences that are interesting targets because these peptides do not have a constant tertiary structure. This phenomenon may facilitate exposure of the epitopes in the native protein, thereby facilitating access to the antibodies.
Epitopes 1 and 2 located near the C-terminus could have this characteristic to our results for the prediction of intrinsically disordered protein regions.

The signal peptide is usually cleaved during post-translational modification of the protein. Signal peptide prediction is used in reverse vaccinology to select proteins that are likely to be secreted by the target cell of the agent. However, these sequences should not be included in the selected peptide sequences because they typically do not form part of the final structure of the mature protein. The Bm86-CG protein does not appear to have a signal peptide according to the signalP algorithm (data not shown). This fact is due to the Bm86-CG sequence deposited in GenBank is a partial sequence of the whole protein, which lacks amino acids at the signal peptide site. On the other hand, full Bm86 sequences, such as from isolate $\mathrm{N} 1$ from a Thailand strain, present a signal peptide of 20 amino acids, as showed by signal algorithm (data not shown). The prediction of GPI anchors in combination with signal peptide prediction allows us to infer that the protein is anchored in a biological membrane. However, we did not observe a GPI anchor based on PderGPI results (data not shown). Additionally, we can infer its possible location, which is a factor that can enhance the triggering of an immune response in the host. 


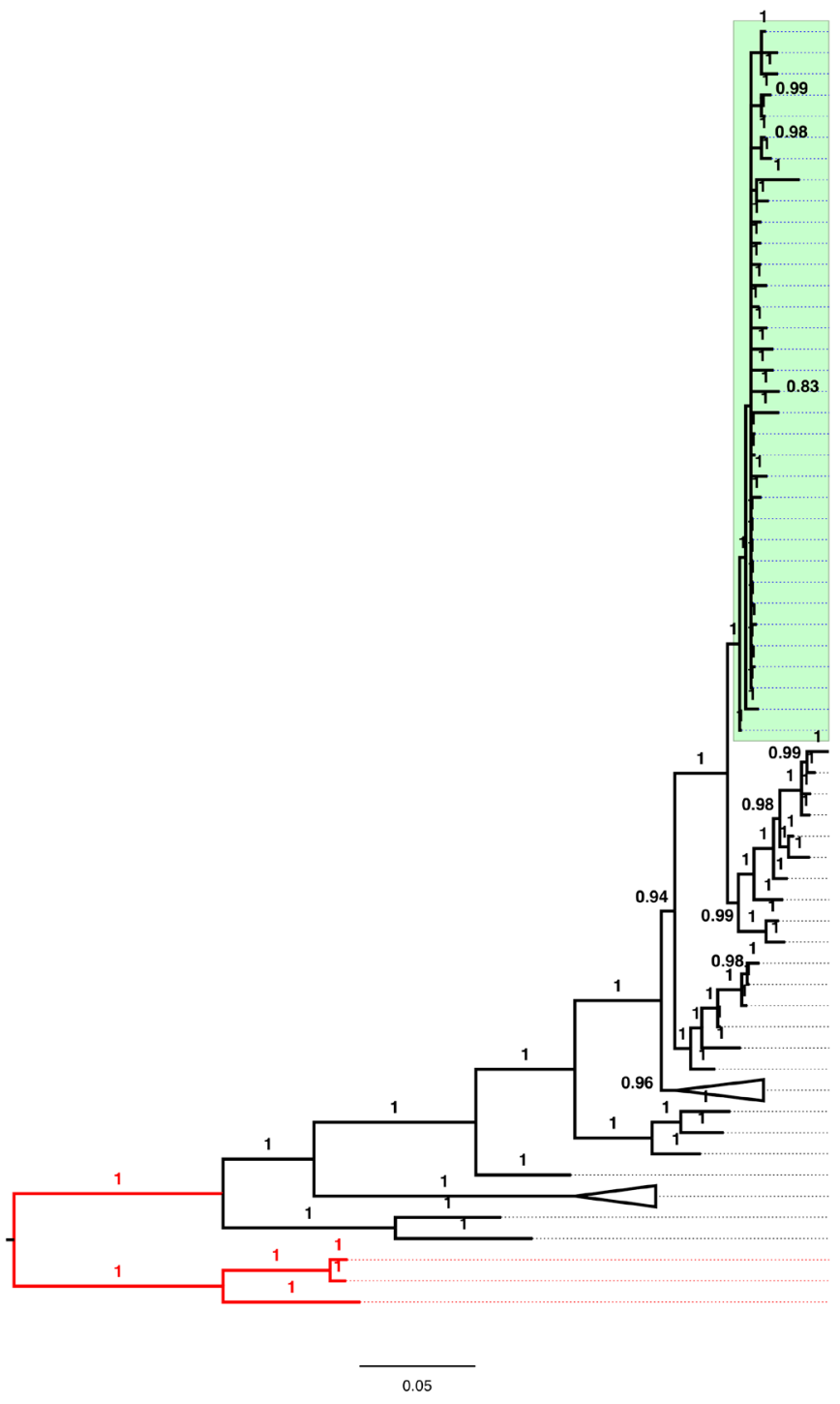

AAW31854 R. microplus - VENEZUELA (Sossai et al., 2005) AAW31853 R. microplus - VENEZUELA (Sossai et al., 2005) AAW72942 R. microplus - URUGUAY (Sossai et al., 2005) AAW72965 R. microplus - RO - BRAZIL (Sossai et al., 2005) AAW72948 R. microplus - MS - BRAZIL (Sossai et al., 2005) AAW72956 R. microplus - MG - BRAZIL (Sossai et al., 2005) AAW72957 R. microplus - MG - BRAZIL (Sossai et al., 2005) AAW72954 R. microplus - MG - BRAZIL (Sossai et al., 2005) ADQ19688 R. microplus - USA (Freeman et al., 2010) AAW72958 R. microplus - MG - BRAZIL (Sossai et al., 2005) AAW72968 R. microplus - MG - BRAZIL (Sossai et al., 2005) AAW72947 R. microplus - MG - BRAZIL (Sossai et al., 2005) AAW72946 R. microplus - RJ - BRAZIL (Sossai et al., 2005) AAW72949 R. microplus - RS - BRAZIL (Sossai et al., 2005) AAW72952 R. microplus - RS - BRAZIL (Sossai et al., 2005) AAW72941 R. microplus - URUGUAY (Sossai et al., 2005) AAW72945 R. microplus - MA - BRAZIL (Sossai et al., 2005) AAW72953 R. microplus - RS - BRAZIL (Sossai et al., 2005) AAW72960 R. microplus - SP - BRAZIL (Sossai et al., 2005) AAW72963 R. microplus - PI - BRAZIL (Sossai et al., 2005) AAW72964 R. microplus - PA - BRAZIL (Sossai et al., 2005) AAU95765 R. microplus - ARGENTINA (Sossai et al., 2005) AAU95764 R. microplus - COLOMBIA (Sossai et al., 2005) ACA57829 R. microplus - BRAZIL (Andreotti et al., 2008) ADQ19684 R. microplus - USA (Freeman et al., 2010) ADQ19683 R. microplus - USA (Freeman et al., 2010) ADQ19685 R. microplus - USA (Freeman et al., 2010) ADQ19677 R. microplus - USA (Freeman et al., 2010) ADQ19690 R. microplus - USA (Freeman et al., 2010) ADQ19680 R. microplus - USA (Freeman et al., 2010) ADQ19689 R. microplus - USA (Freeman et al., 2010) ACR19243 R. microplus - MEXICO (Canales et al., 2009) AAD38381- GAVAC-R. microplus - Argentina (Garcia-Garcia et al., 2000) ADQ19686 R. microplus - USA (Freeman et al., 2010)

ATW75473 R. australis - NEW CALEDONIA (Hüe et al. 2017) ATW75474 R, australis - NEW CALEDONIA (Hüe et al. 2017) ATW75472 R. australis - NEW CALEDONIA (Hüe et al. 2017) ATW75475 R. australis - NEW CALEDONIA (Hüe et al. 2017) P20736 R. australis (Willadsen et al., 1989)

ATW75471 R. australis - NEW CALEDONIA (Hüe et al. 2017) ATW75476 R. australis - NEW CALEDONIA (Hüe et al. 2017) ADM86722 R. microplus - INDIA (Kumar et al., 2010) ACZ55133 R. microplus - MOZAMBIQUE (Nijhof et al., 2009) ABY58968 R. microplus - MOZAMBIQUE (Canales et al., 2008) ACR19242 R. annulatus - USA (Canales et al., 2009) ADQ19693 R. annulatus - USA (Freeman et al., 2010) ADQ19691 R. annulatus - USA (Freeman et al., 2010) ADQ19687 R. microplus - USA (Freeman et al., 2010) ACL27210 R. annulatus - EGYPT (Shahein et al., 2008) ABY58969 R. annulatus - ISRAEL(Canales et al,, 2008) Clade-R. microplus - THAILAND (25 sequences) (Kaewmongkol et al., 2015) ABG21131 R. decoloratus (Odongo et al., 2007) ABY58970 R. decoloratus - SOUTH AFRICA (Canales et al., 2008) ABG21130 R. decoloratus (Odongo et al., 2007) ADR01312 R. evertsi - SOUTH AFRICA (Nijhof et al., 2010) Clade R. appendiculatus (42 sequences) (Nijhof et al., 2009; Kamau et al., 2011; Kamau et al., 2016) $A B N 11119$ R. sanguineus (Fang; $X u, 2007$ )

AJQ81028 R. sanguineus - CUBA (Abella et al., 2014)

AEK31101 Hyalomma detritum - TUNISIA (Nijhof et al., 2012)

AEK31102 Hyalomma detritum - TUNISIA (Said et al., 2012)

ACD14076 Hyalomma anatolicum - INDIA (Jeyabal et al., 2010)

Figure 5. Bayesian phylogenetic tree for partial protein Bm86 (83-340 aa). Populations of Rhipicephalus microplus are shown in blue. The clade shown in red includes Hyalomma detritum and Hyalomma anatolicum (GenBank: AEK21101-102, ACD14076) and was used as an external group.

Alignment of the sequences of $\mathrm{Bm} 86$ proteins from distinct isolates allowed us to identify highly conserved regions (Supplementary Material Figure S1) that could be used to create a vaccine that is based on subunits/peptides. However, these regions do not coincide with the antigenic regions of bovine $\mathrm{Bm} 86$ that are capable of binding to the bovine MHC. Thus, when the animal is exposed to $\mathrm{Bm} 86$, its antigen-presenting cells (APCs) will process the antigen but will present only peptides from variable regions to CD4+ T lymphocytes via MHC class II. This process may result in nonspecific immune responses against these different strains.

A review by Parizi et al. (2012) indicate that the decades-long search for a universal tick vaccine is making progress, with such a vaccine likely to be based on multiple antigens and consequently successful vaccinations against multiple tick species. Our study shows progress towards a universal tick vaccine, that presented three conserved epitopes for regions of the $\mathrm{Bm} 86$ protein. Investigation of Hue et al. (2017) an experimental vaccine was developed based on the orthologous $R$. australis $\mathrm{Bm} 86$ sequence identified from local $R$. australis strains and a recombinant protein expressed in Escherichia coli. The use of the vaccine reduced the population by $74.2 \%$ to each generation. These data once again demonstrate that it is possible to direct for a universal anti-tick vaccine.

De la Fuente et al. (2016) in the review work on vaccine strategies reports the caution should thus be placed on extrapolating the protective abilities of a specific antigen between tick species, as was seen in the case of $\mathrm{Bm} 86$ vaccines. It is worth mentioning, that new approaches to tick control depend on host-parasite interactions. Thus, the efficacy of a vaccine also stems from the clarification of the different immunological profiles presented by the hosts, where bovine tick resistance is a hereditary phenotype (KASHINO et al., 2005; CARVALHO et al., 2010).

The present study showed that based on $\mathrm{Bm} 86, R$. microplus populations were homogeneous and displayed high convergence among the isolates studied by García-García et al. (2000), Sossai et al. (2005), Andreotti et al. (2008), Canales et al. (2009), Nijhof et al. (2009), Freeman et al. (2010); strains of $R$. 
microplus - THAILAND (KAEWMONGKOL et al., 2015); and Bm86 orthologs of $R$. microplus, such as $R$. annulatus (ABY58969) and $R$. decoloratus (ABY58970, ABG21130, ABG21131). Therefore, the results in the present study (Figures 4 and 5) suggest that the polymorphisms were not computed as significant changes and that all these peptides (Figures 2, 3 and 4) with polymorphic sites are more conserved when compared with the partial Bm86 protein sequence (Figure 5).

Interestingly, the strain reported by Willadsen et al. (1989) (P20736) and from Hüe et al. (2017) (ATW75471 -76) remained in the clade along with the other Bm86 strains (Figure 4). It is worth remembering that the cattle tick, previously named $R$. microplus until its morphological and genetic distinction to $R$. australis (ESTRADA-PEÑA et al., 2012). These strains obtained high convergence with the other strains of $R$. microplus for epitope 3 . As this strain could produce an ortholog of $R$. microplus $\mathrm{Bm} 86$, this peptide could become a vaccine candidate for both $R$. microplus and $R$. australis.

Canales et al. (2009) showed that the Ba86 protein (an ortholog of $\mathrm{Bm} 86$ from $R$. microplus) is effective in controlling infestation with $R$. annulatus and $R$. microplus. This ortholog was shown to have low convergence in the tree with the partial $\mathrm{Bm} 86$ protein (ACR19242) (Figure 5). However, the chosen epitopes have been preserved for this ortholog, and may continue to be efficient in cross-immunity. This shows even orthologs have conserved regions and could be effective antigenic and immunogenic regions.

Differences were observed in the phylogenetic trees of epitope 1 and for total protein Bm86 (Figures 2 and 5) in the Thailand variants, which formed a distinct clade from the other $R$. microplus sequences. These differences could hinder the development of a global vaccine for these variants. However, epitopes 2 and 3 (Figures 3 and 4) presented a larger and more homogeneous clade with convergence among the $R$. microplus Thailand populations (Figure 3), suggesting that this epitope was more conserved and could generate a potential immunogen among the Thailand variants described by Kaewmongkol et al. (2015).

Kamau et al. (2016) demonstrated that intestinal cDNA from four Rhipicephalus appendiculatus field populations revealed genotypic polymorphisms and suggested that other factors such as exposure to innate immune components during blood feeding may direct the selection pressure that leads to the observed polymorphisms. Additional polymorphisms may have occurred during the evolution of the $R$. microplus populations (SOSSAI et al., 2005). Population studies performed by Csordas et al. (2016) with the cytochrome c oxidase subunit 1 (COI-1) gene indicated the presence of two haplotypes that differ from other Brazilian $R$. microplus populations. Thus, their antigenic epitopes may have become distinct from the epitopes of other populations. This possibility may indicate that most antigenic characteristics are not located in regions conserved in the Bm86-CG protein but instead are located in more variable regions.

Importantly, some convergence was observed for each phylogenetic tree of each selected epitope, resulting in their distribution among several geographic areas. Conversely, when the entire amino acid sequence of the Bm86-CG protein was analyzed (Figure 5), the polymorphisms formed several clusters associated with various geographic regions. This work presents peptides for a vaccine that has point polymorphisms between conserved regions of the epitopes, but this does not interfere in the immunogenic and antigenic regions and may be candidates for a global vaccine. The in silico analysis presented here can be an important tool for related tick populations that have not been challenged with the Bm86 antigen in order to minimize future economic problems arising from infestations.

\section{Conclusion}

The phylogenetic analysis of the isolated epitopes and the Bm86-CG protein revealed geographical patterns among $R$. microplus tick isolates collected from the database; these isolates were classified into a major clade based on their amino acid sequences. These sequences may contain epitopes with amino acid residues that have both conserved and antigenic regions. However, this characteristic is found in most variable regions of the protein.

Considering the extensive sequence and functional polymorphism observed among strains of $R$. microplus from different geographical regions, we can conclude that it may be possible to achieve effective vaccination against these cattle ticks using a single universal Bm86-based antigen. These point polymorphisms in some amino acids do not form in a less conserved peptide, not altering their antigenic or immunogenic capacity. As genomic technologies in vaccine development continue to improve and evolve, sequencing of various tick genomes can identify tick vaccine candidates globally applicable to various species of ticks.

\section{Acknowledgements}

This study was supported by the Coordenação de Aperfeiçoamento de Pessoal de Nível Superior (Capes), Conselho Nacional de Desenvolvimento Científico e Tecnológico (CNPq), and Fundação de Apoio ao Desenvolvimento do Ensino, Ciência e Tecnologia do Estado de Mato Grosso do Sul (Fundect, MS) - Governo do Estado de Mato Grosso do Sul. The funders had no role in the study design, data collection and analysis, decision to publish, or preparation of the manuscript.

\section{References}

Aguirre AAR, Lobo FP, Cunha RC, Garcia MV, Andreotti R. Design of the ATAQ peptide and its evaluation as an immunogen to develop a Rhipicephalus vaccine. Vet Parasitol 2016; 221: 30-38. http://dx.doi. org/10.1016/j.vetpar.2016.02.032. PMid:27084468.

Andreotti R, Guerrero FD, Soares MA, Barros JC, Miller RJ, Léon AP. Acaricide resistance of Rhipicephalus (Boophilus) microplus in State of Mato Grosso do Sul, Brazil. Rev Bras Parasitol Vet 2011; 20(2): 127-133. http:// dx.doi.org/10.1590/S1984-29612011000200007. PMid:21722487.

Andreotti R, Pedroso MS, Caetano AR, Martins NF. Comparison of predicted binders in Rhipicephalus (Boophilus) microplus intestine protein variants Bm86 Campo Grande Strain, Bm86 and Bm95. Rev Bras Parasitol Vet 2008; 17(2): 93-98. http://dx.doi.org/10.1590/S198429612008000200006 . PMid:18823577. 
Andreotti R. Performance of two Bm86 antigen vaccine formulation against tick using crossbreed bovines in stall test. Rev Bras Parasitol Vet 2006; 15(3): 97-100. PMid:16978472.

Barré N, Uilenberg G. Spread of parasites transported with their hosts: case study of two species of cattle tick. Rev Sci Tech 2010; 29(1): 149-160.

Barrero RA, Guerrero FD, Black M, McCooke J, Chapman B, Schilkey F, et al. Gene-enriched draft genome of the cattle tick Rhipicephalus microplus: assembly by the hybrid Pacific Biosciences/Illumina approach enabled analysis of the highly repetitive genome. Int J Parasitol 2017; 47(9): 569-583. http://dx.doi.org/10.1016/j.ijpara.2017.03.007. PMid:28577881.

Ben-Yedidia T, Arnon R. Design of peptide and polypeptide vaccines. Curr Opin Biotechnol 1997; 8(4): 442-448. http://dx.doi.org/10.1016/ S0958-1669(97)80066-3. PMid:9265723.

Bovimune Ixovac. [online]. México: Lapisa; 2018 [cited 2018 July 20]. Available from: http://www.ixovac.com/

Burger TD, Shao R, Barker SC. Phylogenetic analysis of mitochondrial genome sequences indicates that the cattle tick, Rhipicephalus (Boophilus) microplus, contains a cryptic species. Mol Phylogenet Evol 2014; 76: 241 253. http://dx.doi.org/10.1016/j.ympev.2014.03.017. PMid:24685498.

Canales M, Almazán C, Naranjo V, Jongejan F, de la Fuente J. Vaccination with recombinant Boophilus annulatus $\mathrm{Bm} 86$ ortholog protein, $\mathrm{Ba} 86$, protects cattle against $B$. annulatus and $B$. microplus infestations. $B M C$ Biotechnol 2009; 9(1): 29. http://dx.doi.org/10.1186/1472-6750-9-29. PMid:19335900.

Canales M, de la Lastra JM, Naranjo V, Nijhof AM, Hope M, Jongejan F, et al. Expression of recombinant Rhipicephalus (Boophilus) microplus, $R$. annulatus and $R$. decoloratus $\mathrm{Bm} 86$ orthologs as secreted proteins in Pichia pastoris. BMC Biotechnol 2008; 8(1): 14. http://dx.doi. org/10.1186/1472-6750-8-14. PMid:18275601.

Canales M, Enríquez A, Ramos E, Cabrera D, Dandie H, Soto A, et al. Large-scale production in Pichia pastoris of the recombinant vaccine Gavac against cattle tick. Vaccine 1997; 15(4): 414-422. http://dx.doi. org/10.1016/S0264-410X(96)00192-2. PMid:9141213.

Carvalho WA, Franzin AM, Abatepaulo ARR, Oliveira CJF, Moré DD, Silva JS, et al. Modulation of cutaneous inflammation induced by ticks in contrasting phenotypes of infestation in bovines. Vet Parasitol 2010; 167(2-4): 260-273. http://dx.doi.org/10.1016/j.vetpar.2009.09.028. PMid:19836891.

Cobon G, Hungerford J, Woodrow M, Smith D, Willadsen P. Vaccination against Boophilus microplus: the Australian field experience. In: de la Fuente J. Recombinant vaccines for the control of cattle tick, Elfos Scintiae: Havana; 1995. p. 163-176.

Contreras M, Villar M, Alberdi P, de la Fuente J. Vaccinomics approach to tick vaccine development. Methods Mol Biol 2016; 1404: 275-286. http://dx.doi.org/10.1007/978-1-4939-3389-1_19. PMid:27076305.

Csordas BG, Garcia MV, Cunha RC, Giachetto PF, Blecha IMZ, Andreotti R. New insights from molecular characterization of the tick Rhipicephalus (Boophilus) microplus in Brazil. Rev Bras Parasitol Vet 2016; 25(3): 317 326. http://dx.doi.org/10.1590/S1984-29612016053. PMid:27579530.

Cunha RC, Pérez de León AA, Leite FPL, Pinto LS, Santos AG Jr, Andreotti R. Bovine immunoprotection against Rhipicephalus (Boophilus) microplus with recombinant Bm86-Campo Grande antigen. Rev Bras Parasitol Vet 2012; 21(3): 254-262. http://dx.doi.org/10.1590/S198429612012000300014 . PMid:23070436.
Dayhoff MO, Schwartz RM, Orcutt BC. A model of evolutionary change in proteins. In: Dayhoff MO. Atlas of Protein Sequence and Structure. Silver Spring: National Biomedical Research Foundation; 1978. p. 345352. (suppl. 3; vol. 5)

De Groot AS. Immunomics: discovering new targets for vaccines and therapeutics. Drug Discov Today 2006; 11(5-6): 203-209. http://dx.doi. org/10.1016/S1359-6446(05)03720-7. PMid:16580597.

de la Fuente J, Kopáček P, Lew-Tabor A, Maritz-Olivier C. Strategies for new and improved vaccines against ticks and tick-borne diseases. Parasite Immunol 2016; 38(12): 754-769. http://dx.doi.org/10.1111/ pim.12339. PMid:27203187.

de la Fuente J, Rodríguez M, Montero C, Redondo M, García-García JC, Méndez L, et al. Vaccination against ticks (Boophilus spp.): the experience with the Bm86-based vaccine Gavac. Genet Anal 1999; 15(3-5): 143-148. http://dx.doi.org/10.1016/S1050-3862(99)00018-2. PMid:10596754.

DTU bioinformatics. TMHMM Server v. 2.0. Prediction of transmembrane helices in proteins [online]. Denmark: Departament of Bio and Health Informatics; 2018a [cited 2018 July 20]. Available from: http://www. cbs.dtu.dk/services/TMHMM/

DTU bioinformatics. SignalP 4.1 Server [online]. Denmark: Departament of Bio and Health Informatics; 2018b [cited 2018 July 20]. Available from: http://www.cbs.dtu.dk/services/SignalP/

Estrada-Peña A, Venzal JM, Nava S, Mangold A, Guglielmone AA, Labruna MB, et al. Reinstatement of Rhipicephalus (Boophilus) australis (Acari: Ixodidae) with redescription of the adult and larval stages. J Med Entomol 2012; 49(4): 794-802. http://dx.doi.org/10.1603/ME11223. PMid:22897039.

Florea L, Halldórsson B, Kohlbacher O, Schwartz R, Hoffman S, Celera SI. Epitope prediction algorithms for peptide-based vaccine design. Proc IEE Comput Biol Conf 2003; 2: 17-26.

Freeman JM, Davey RB, Kappmeyer LS, Kammlah DM, Olafson PU. Bm86 midgut protein sequence variation in South Texas cattle fever ticks. Parasit Vectors 2010; 3(1): 101. http://dx.doi.org/10.1186/17563305-3-101. PMid:21047431.

Fries R, Eggen A, Womack JE. The bovine genome map. Mamm Genome 1993; 4(8): 405-428. http://dx.doi.org/10.1007/BF00296815. PMid:8104056.

Fries R, Hediger R, Stranzinger G. Tentative chromosomal localization of the bovine major histocompatibility complex by in situ hybridization. Anim Genet 1986; 17(4): 287-294. PMid:3103495.

García-García JC, Gonzalez IL, González DM, Valdés M, Méndez L, Lamberti J, et al. Sequence variantions in the Boophilus microplus Bm86 locus and implications for immunoprotection in cattle vaccinated with this antigen. Exp Appl Acarol 1999; 23(11): 883-895. http://dx.doi. org/10.1023/A:1006270615158. PMid:10668863.

García-García JC, Montero C, Redondo M, Vargas M, Canales M, Boue $\mathrm{O}$, et al. Control of ticks resistant to immunization with $\mathrm{Bm} 86$ in cattle vaccinated with the recombinant antigen $\mathrm{Bm} 95$ isolated from the cattle tick, Boophilus microplus. Vaccine 2000; 18(21): 2275-2287. http://dx.doi.org/10.1016/S0264-410X(99)00548-4. PMid:10717348.

Grisi L, Leite RC, Martins JRS, Barros ATM, Andreotti R, Cançado $\mathrm{PH}$, et al. Reassessment of the potential economic impact of cattle parasites in Brazil. Rev Bras Parasitol Vet 2014; 23(2): 150-156. http:// dx.doi.org/10.1590/S1984-29612014042. PMid:25054492.

Hüe T, Petermann J, Bonnefond R, Mermoud I, Rantoen D, Vuocolo T. Experimental efficacy of a vaccine against Rhipicephalus australis. Exp 
Appl Acarol 2017; 73(2): 245-256. http://dx.doi.org/10.1007/s10493017-0184-0. PMid:29110171.

Immune Epitope Database and Analysis Resource - IEDB. MHC-I binding predictions [online]. Rockville: Bethesda; National Institute of Allergy and Infectious Diseases; 2018a [cited 2018 July 20]. Available from: http://tools.iedb.org/mhci/

Immune Epitope Database and Analysis Resource - IEDB. MHC-II binding predictions [online]. Rockville: Bethesda; National Institute of Allergy and Infectious Diseases; 2018b [cited 2018 July 20]. Available from: http://tools.iedb.org/mhcii/

Immune Epitope Database and Analysis Resource - IEDB. Antibody Epitope Prediction (Bepipred Linear Epitope Prediction) [online]. Rockville: Bethesda; National Institute of Allergy and Infectious Diseases; 2018c [cited 2018 July 20]. Available from: http://tools.iedb.org/bcell

Immune Epitope Database and Analysis Resource - IEDB. Antibody Epitope Prediction (Emini Surface Accessibility Prediction) [online]. Rockville: Bethesda; National Institute of Allergy and Infectious Diseases; 2018d[cited 2018 July 20]. Available from: http://tools.iedb.org/bcell

IUPred2A. Prediction of intrinsically unstructured proteins [online]. Hungary IUPred2A; 2018 [cited 2018 July 20]. Available from: https:// iupred2a.elte.hu/

Jonsson NN, Matschoss AL, Pepper P, Green PE, Albrecht MS, Hungerford J, et al. Evaluation of TickGARD ${ }^{\text {PLUs }}$, a novel vaccine against Boophilus microplus, in lactating Holstein-Friesian cows. Vet Parasitol 2000; 88(34): 275-285. http://dx.doi.org/10.1016/S0304-4017(99)00213-7. PMid:10714465.

Kaewmongkol S, Kaewmongkol G, Inthong N, Lakkitjaroen N, Sirinarumitr T, Berry CM, et al. Variation among Bm86 sequences in Rhipicephalus (Boophilus) microplus ticks collected from cattle across Thailand. Exp Appl Acarol 2015; 66(2): 247-256. http://dx.doi.org/10.1007/s10493015-9897-0. PMid:25777941.

Kamau L, Skilton RA, Odongo DO, Mwaura S, Githaka N, Kanduma E, et al. Differential transcription of two highly divergente gut-expressed Bm86 antigen gene homologues in the tick Rhipicephalus appendiculatus (Acari: Ixodida). Insect Mol Biol 2011; 20(1): 105-114. http://dx.doi. org/10.1111/j.1365-2583.2010.01043.x. PMid:20854482.

Kamau LM, Skilton RA, Githaka N, Kiara H, Kabiru E, Shah T, et al. Extensive polymorphism of Ra86 genes in field populations of Rhipicephalus appendiculatus from Kenya. Ticks Tick Borne Dis 2016; 7(5): 772-781. http://dx.doi.org/10.1016/j.ttbdis.2016.03.011. PMid:27051976.

Kashino SS, Resende J, Sacco AM, Rocha C, Proença L, Carvalho WA, et al. Boophilus microplus: the pattern of bovine immunoglobulin isotype responses to high and low tick infestations. Exp Parasitol 2005; 110(1): 12-21. http://dx.doi.org/10.1016/j.exppara.2005.01.006. PMid:15804374.

Kast WM, Roux L, Curren J, Blom HJJ, Voordouw AC, Meloen RH, et al. Protection against lethal Sendai virus infection by in vivo priming of virus-specific cytotoxic T lymphocytes with a free synthetic peptide. Proc Natl Acad Sci USA 1991; 88(6): 2283-2287. http://dx.doi.org/10.1073/ pnas.88.6.2283. PMid:1848698.

Kopp N, Diaz D, Amacker M, Odongo DO, Beier K, Nitsch C, et al. Identification of a synthetic peptide inducing cross-reactive antibodies binding to Rhipicephalus (Boophilus) decoloratus, Rhipicephalus (Boophilus) microplus, Hyalomma anatolicum anatolicum and Rhipicephalus appendiculatus BM86 homologues. Vaccine 2009; 28(1): 261-269. http://dx.doi. org/10.1016/j.vaccine.2009.09.085. PMid:19808026.
Labruna MB, Naranjo V, Mangold JA, Thompson C, Estrada-Peña A, Guglielmone AA, et al. Allopatric speciation in ticks: genetic and reproductive divergence between geographic strains of Rhipicephalus (Boophilus) microplus. BMC Evol Biol 2009; 9(1): 46-58. http://dx.doi. org/10.1186/1471-2148-9-46. PMid:19243585.

Lewin HA. Genetic organization, polymorphism, and function of the bovine major histocompatibility complex. In: Schook LB, Lamont SJ, editors. The major histocompatibility complex region of domestic animal species. 4th ed. Boca Raton: CRC Series in Comparative Immunology; 1996. p. 65-98.

Lew-Tabor AE, Rodriguez Valle M. A review of reverse vaccinology approaches for the development of vaccines against ticks and tick borne diseases. Ticks Tick Borne Dis 2016; 7(4): 573-585. http://dx.doi. org/10.1016/j.ttbdis.2015.12.012. PMid:26723274.

Low VL, Tay ST, Kho KL, Koh FX, Tan TK, Lim YA, et al. Molecular characterization of the tick Rhipicephalus microplus in Malaysia: new insights into the cryptic diversity and distinct genetic assemblages throughout the world. Parasit Vectors 2015; 8(1): 341. http://dx.doi.org/10.1186/ s13071-015-0956-5. PMid:26104478.

McShane RD, Gallagher DS Jr, Newkirk H, Taylor JF, Burzlaff JD, Davis SK, et al. Physical localization and order of genes in the class I region of the bovine MHC. Anim Genet 2001; 32(5): 235-239. http://dx.doi. org/10.1046/j.1365-2052.2001.00758.x. PMid:11683708.

National Center for Biotechnology Information - NCBI. BLAST: Basic Local Alignment Search Tool [online]. Rockville: Bethesda Softworks; 2018 [cited 2018 July 20]. Available from: https://blast.ncbi.nlm.nih. gov/BlastAlign.cgi

Nene V, Svitek N, Toye P, Golde WT, Barlow J, Harndahl M, et al. Designing bovine $T$ cell vaccines via reverse immunology. Ticks Tick Borne Dis 2012;3(3): 188-192. http://dx.doi.org/10.1016/j.ttbdis.2011.12.001. PMid:22621863.

Nijhof AM, Balk JA, Postigo M, Jongejan F. Selection of reference genes for quantitative RT-PCR studies in Rhipicephalus (Boophilus) microplus and Rhipicephalus appendiculatus ticks and determination of the expression profile of Bm86. BMC Mol Biol 2009; 10(1): 112. http:// dx.doi.org/10.1186/1471-2199-10-112. PMid:20040102.

Odongo D, Kamau L, Skilton R, Mwaura S, Nitsch C, Musoke A, et al. Vaccination of cattle with TickGARD induces cross-reactive antibodies binding to conserved linear peptides of $\mathrm{Bm} 86$ homologues in Boophilus decoloratus. Vaccine 2007; 25(7): 1287-1296. http://dx.doi.org/10.1016/j. vaccine.2006.09.085. PMid:17070625.

Parizi LF, Githaka NW, Logullo C, Konnai S, Masuda A, Ohashi K, et al. The quest for a universal vaccine against ticks: cross-immunity insights. Vet J2012; 194(2): 158-165. http://dx.doi.org/10.1016/j.tvjl.2012.05.023. PMid:22766309.

Patarroyo JH, Portela RW, Castro RO, Couto Pimentel J, Guzman F, Patarroyo ME, et al. Immunization of cattle with synthetic peptides derived from the Boophilus microplus gut protein (Bm86). Vet Immunol Immunopathol 2002; 88(3-4): 163-172. http://dx.doi.org/10.1016/ S0165-2427(02)00154-X. PMid:12127414.

Peconick AP, Sossai S, Girão FA, Rodrigues MQ, Souza e Silva CH, Guzman Q F, et al. Synthetic vaccine (SBm7462) against the cattle tick Rhipicephalus (Boophilus) microplus: preservation of immunogenic determinants in different strains from South America. Exp Parasitol 2008; 119(1):37-43. http://dx.doi.org/10.1016/j.exppara.2007.12.007. PMid:18226809. 
Pierleoni A, Martelli PL, Casadio R. PredGPI: a GPI-anchor predictor. BMC Bioinformatics 2008; 9(1): 392. http://dx.doi.org/10.1186/14712105-9-392. PMid:18811934.

Rand KN, Moore T, Sriskantha A, Spring K, Tellam R, Willadsen P, et al. Cloning and expression of a protective antigen from the cattle tick Boophilus microplus. Proc Natl Acad Sci USA 1989; 86(24): 9657-9661. http://dx.doi.org/10.1073/pnas.86.24.9657. PMid:2690068.

Reck J, Klafke GM, Webster A, Dall'Agnol B, Scheffer R, Souza UA, et al. First report of fluazuron resistance in Rhipicephalus microplus: a field tick population resistant to six classes of acaricides. Vet Parasitol 2014; 201(1-2): 128-136. http://dx.doi.org/10.1016/j.vetpar.2014.01.012. PMid:24560364.

Richardson MA, Smith DR, Kemp DH, Tellam RL. Native and baculovirusexpressed forms of the immuno-protective protein Bm86 from Boophilus microplus are anchored to the cell membrane by a glycosyl-phosphatidyl inositol linkage. Insect Mol Biol 1993; 1(3): 139-147. http://dx.doi. org/10.1111/j.1365-2583.1993.tb00115.x. PMid:8269092.

Riek RF. Studies on the reactions of animals to infestation with ticks. VI. Resistance of cattle to infestation with the tick Boophilus microplus (Canestrini). Aust J Agric Res 1962; 13(3): 532-550. http://dx.doi. org/10.1071/AR9620532.

Rodríguez M, Rubiera R, Penichet M, Montesinos R, Cremata J, Falcón $\mathrm{V}$, et al. High level expression of the B. microplus $\mathrm{Bm} 86$ antigen in the yeast Pichia pastoris forming highly immunogenic particles for cattle. J Biotechnol 1994; 33(2): 135-146. http://dx.doi.org/10.1016/01681656(94)90106-6. PMid:7764729.

Rodriguez-Valle M, Moolhuijzen P, Piper EK, Weiss O, Vance M, Bellgard $\mathrm{M}$, et al. Rhipicephalus microplus lipocalins (LRMs): Genomic identification and analysis of the bovine immune response using in silico predicted $\mathrm{B}$ and T cell epitopes. Int J Parasitol 2013; 43(9): 739-752. http://dx.doi. org/10.1016/j.ijpara.2013.04.005. PMid:23747800.

Ronquist F, Huelsenbeck JP. MRBAYES 3: bayesian phylogenetic inference under mixed models. Bioinformatics 2003; 19(12): 1572-1574. http:// dx.doi.org/10.1093/bioinformatics/btg180. PMid:12912839.

Singh NK, Gelot IS, Jyoti, Singh V, Rath SS. Detection of amitraz resistance in Rhipicephalus (Boophilus) microplus from North Gujarat, India. J Parasit Dis 2015; 39(1): 49-52. http://dx.doi.org/10.1007/ s12639-013-0280-y. PMid:25698859.

Sitte K, Brinkworth R, East IJ, Jazwinska EC. A single amino acid deletion in the antigen binding site of BoLA-DRB3 is predicted to affect peptide binding. Vet Immunol Immunopathol 2002; 85(3-4): 129-135. http://dx.doi.org/10.1016/S0165-2427(01)00430-5. PMid:11943314.
Sossai S, Peconick AP, Sales-Junior PA, Marcelino FC, Vargas MI, Neves ES, et al. Polymorphism of the bm86 gene in South American strains of the cattle tick Boophilus microplus. Exp Appl Acarol 2005; 37(3-4): 199214. http://dx.doi.org/10.1007/s10493-005-3262-7. PMid:16323051.

Sutherst RW, Bourne AS. Modelling non-equilibrium distributions of invasive species: a tale of two modeling paradigms. Biol Invasions 2009; 11(6): 1231-1237. http://dx.doi.org/10.1007/s10530-008-9335-x.

Szabó MPJ, Bechara GH. Sequential histopathology at the Rhipicephalus sanguineus tick feeding site on dogs and guinea pigs. Exp Appl Acarol 1999; 23(11): 915-928. http://dx.doi.org/10.1023/A:1006347200373. PMid:10668866.

Szabó MPJ. Imunopatologia da resistência de bovinos ao carrapato $R$. (B.) microplus. In: Pereira MC, Labruna MB, Szabó MPJ, Klafke GM. Rhipicephalus (Boophilus) microplus: Biologia, Controle e Resistência. 1st ed. São Paulo: MedVet; 2008. p. 107-126.

Tamura K, Stecher G, Peterson D, Filipski A, Kumar S. MEGA6: Molecular Evolutionary Genetics Analysis version 6.0. Mol Biol Evol 2013; 30(12): 2725-2729. http://dx.doi.org/10.1093/molbev/mst197. PMid:24132122.

Toes REM, Offringa R, Blom RJJ, Melief CJM, Kast WM. Peptide vaccination can lead to enhance tumor growth through specific T-cell tolerance induction. Proc Natl Acad Sci USA 1996; 93(15): 7855-7860. http://dx.doi.org/10.1073/pnas.93.15.7855. PMid:8755566.

Tree Bio. FigTree [online]. London: Tree Bio; 2016 [cited 2017 Mar 02]. Available from: http://tree.bio.ed.ac.uk/

Vargas M, Montero C, Sánchez D, Pérez D, Valdés M, Alfonso A, et al. Two initial vaccinations with the Bm86-based Gavacplus vaccine against Rhipicephalus (Boophilus) microplus induce similar reproductive suppression to three initial vaccinations under production conditions. BMC Vet Res 2010; 6(1): 43. http://dx.doi.org/10.1186/1746-6148-643. PMid:20846415.

Vordermeier M, Whelan AO, Hewinson RG. Recognition of mycobacterial epiptopes by $\mathrm{T}$ cells across mammalian species and use of a program that predicts human HLA-DR binding peptides to predict bovine epitopes. Infect Immun 2003; 71(4): 1980-1987. http://dx.doi.org/10.1128/ IAI.71.4.1980-1987.2003. PMid:12654816.

Willadsen P, Bird P, Cobon GS, Hungerford J. Commercialisation of a recombinant vaccine against Boophilus microplus. Parasitology 1995;110(S1 Suppl): S43-S50. http://dx.doi.org/10.1017/S0031182000001487. PMid:7784128.

Willadsen P, Riding GA, McKenna RV, Kemp DH, Tellam RL, Nielsen JN, et al. Immunological control of a parasitic arthropod. Identification of a protective antigen from Boophilus microplus. J Immunol 1989; 143(4): 1346-1351. PMid:2745982. 


\section{Supplementary Material}

Supplementary material accompanies this paper.

\section{Bm86p1 aa 566-588}

AJE29940
AJE29930
AJE29932
AAA36098
ACZ55133
ADQ19688
ADQ19690
ACA57829
ADQ19678
ADQ19677
ADQ19679
AJE29929
AJE29941
AJE29939
AJE29951
AJE29933
AJE29949
AJE29945
AJE29937
AJE29948
AJE29952
AJE29946
AJE29934
AJE29935
AJE29944
AJE29950
AJE29936
AJE29947
AJE29927
AJE29925
AJE29926
AJE29931
AJE29924
AJE29942
ADQ19681
ADQ19680
ADQ19682
ADQ19689
AJE29938
AJE29943
AJE29928
ADQ19687
ADQ19686
ADQ19684
ADQ19685
ADQ19683

\section{Bm86p2 aa 560-584}

SSGORCVMENGKAVCKVESGAHT SSEHRCVMENGKAVCKEKSEATT SSGHRCVIENGKAVCKEKTEATT SSGORCVIENGKAVCKEKSEATT SSGQRCVMENGNAVCKEKSDATT SSGQRCVMENGNAVCKEKSDATT SSGQRCVMENGNAVCKEKSDATT SSGQRCVMENGNAVCKEKSDATT SSGORCVIENGNAVCKEKSDATT SSGQRCVMENGNAVCKEKSDATT SSGQRCVIENGNAVCKEKSDATT SSGQRCVMENGKAVCKEKSDATT SSGQGCVMENGKAVCKEKSEATT SSGORCVIENGKAVCKVKSEATT SSGQRCVMENGKAVCKVKSEATT SSGQRCVIENGKAVCKVKSEATT SSGQRCVMENGKAVCKVKSEATT SSGQRCVMENGKAVCKVKSEATT SSGQRCVMENGKAVCKVKSEATT SSGQRCVMENGKAVCKVKSEATT SSGQRCVIENGKAVCKVKSEATT SSGORCVMENGKAVCKVKSEATT SSGQRCVMENGKAVCKVKSEATT SSGQRCVIENGKAVCKVKSEATT SSGQRCVMENGKAVCKVKSEATT SSGQRCVMENGKAVCKVKSEATT SSGORCVIENGKAVCKVKSEATT SSGQRCVMENGKAVCKVKSEATT SSGQRCEVENGKAVCKEKSEATT SSGQRCEVENGKAVCKEKSEATT SSGQRCEVENGKAVCKEKSEATT SSGORCVIENGKAVCKEKSEATT SSGQRCV/UNGKAVCKEKSEATT SSGQRCVMENGKAVCKEKSEATT SSGORCVMENGKAVCKEKSEATT SSGQRCVMENGKAVCKEKSEATT SSGQRCVIENGKAVCKEKSEATT SSGQRCVIENGKAVCKEKSEATT SSGQRCVMENGNAVCKEKSEATT SSGORCVMENGNAVCKEKSEATT SSGQRCVMENGNAVCKEKSEATT SSGQRCVMENGNAVCKEKSEATT SSGQRCVMENGNAVCKEKSEATT SSGQRCVMENGNAVCKEKSEATT SSGORCVMENGNAVCKEKSEATT SSGQRCVMENGNAVCKEKSEATT
AJE29932 AJE29930 AJE29929 AJE29931 A.A.A30098 ADQ19681 ADQ19680 ADQ19682 ADQ19689 ADQ19685 AJE29942 ADQ19687 ACZ55133 ADQ19686 ADQ19684 ADQ19683 ADQ19688 ADQ19690 ACA57829 ADQ19678 ADQ19677 AD019679

AJE29928 AJE29938 AJE29943 AJE29927 AJE29925 AJE29926 AJE29939 AJE29940 AJE29951 AJE29933 AJE29949 AJE29945 AJE29937

AJE29948 AJE29952 AJE29946 AJE29934 AJE29935 AJE29944 AJE29950 AJE29936

AJE29947 AJE29941 AJE29924
KCLDDPECSREPAKDSCNKKENGK KCPDDHSFSREPAKDSCSEKENGK KCPDDHECFREPAKDFCSEENNGK KCPDDHECSREPAKDFCREEGNGK ECPDDHECYREPAKDSCSEEDNGK KCPDDHECSROPAKDSCSEEDNGK KCPDDHECSROPAKDSCSEEDNGK KCPDDHECSRQPAKDSCSEEDNGK KCPDDHECSROPAKDSCSEEDNGK KCPDDHECSRQPAKDSCSEEDNGK KCPDDHECSREPAKDSCSEEDNGK KCPDDHECSREPAKDSCSEEDNGK KCPDDHECSREPAKDSCSEEDNGK KCPDDHECSREPAKDSCSEEDNGK KCPDDHECSREPAKDSCSEEDNGK KCPDDHECSREPAKDSCSEEDNGK KCPDDHECSREPAKDSCSEEDNGK KCPDDHECSREPAKDSCSEEDNGK KCPDDHECSREPAKDSCSEEDNGK KCPDDHECSREPAKDSCSEEDNGK KCPDDHECSREPAKDSCSEEDNGK KCPDDHECSREPAKDSCSEEDNGK ECPDGHECSREPAKDSCSEEDNGK KCPDGHECSREPAKDSCSEEDNGK KCPDGHECSREPAKDSCSEEDNGK KCPDGHECSREPAKDSCSEEDNGK KCPDGHECSREPAKDSCSEEDNGK KCPDGHECSREPAKDSCSEEDNGK KCPDGHECSREPAKDSCSEEDNGK KCPDGHECSREPAKDSCSEEDNGK KCPDGHECSREPAKDSCSEEDNGK KCPDGHECSREPAKDSCSEEDNGK KCPDGHECSREPAKDSCSEEDNGK KCPDGHECSREPAKDSCSEEDNGK KCPDGHECSREPAKDSCSEEDNGK KCPDGHECSREPAKDSCSEEDNGK KCPDGHECSREPAKDSCSEEDNGK KCPDGHECSREPAKDSCSEEDNGK KCPDGHECSREPAKDSCSEEDNGK KCPDGHECSREPAKDSCSEEDNGK KCPDGHECSREPAKDSCSEEDNGK KCPDGHECSREPAKDSCSEEDNGK KCPDGHECSREPAKDSCSEEDNGK KCPDGHECSREPAKDSCSEEDNGK KCPDGHECSREPAKDSCSEEDNGK KCPDGHECFREPAKDSCSEEDNGK $:^{*} * ., \quad * ; * * * * *:: * * *$

\section{Bm86p3 aa 170-189}

AAA30098 ACZ55133 ADQ19687 AJE29931 AJE29932

AJE29938 AJE29943

AJE29927

AJE29925

AJE29926

AJE29941

AJE29942

AJE29929

ADQ19681

AD019680

ADO19682

ADO19689

ADQ19686

ADQ19684

ADQ19685

ADQ19683

AD019688

ADQ19690

ACA57829

ADQ19678

ADQ19677

ADQ19679

AJE29930

AJE29924

AJE29939

AJE29940

AJE29951

AJE29933

AJE29949

AJE29945

AJE29937

AJE29948

AJE29952

AJE29946

AJE29934

AJE29935

AJE29944

AJE29950

AJE29936

AJE29947

AJE29928
DSYCSPGSPKGPDGQCINAC DSYCSPGSPKGPDRQCKNAC DSYCSPGSPKGPDGOCKDAC DSYCSPGSPKGPDGQCKNAC DSYCSPGSPKGPDGOCKNAC DSYCSPGSPKGPDGQCKNAC DSYCSPGSPKGPDGOCKNAC DSYCSPGSPKGPDGOCKNAC DSYCSPGSPKGPDGQCKNAC DSYCSPGSPKGPDGOCKNAC DSYCSPGSPKGPDGOCKNAC DSYCSPGSPKGPDGOCKNAC DSYCSPGSPKGPDGOCKNAC DSYCSPGSPKGPDGQCKNAC DSYCSPGSPKGPDGOCKNAC DSYCSPGSPKGPDGOCKNAC DSYCSPGSPKGPDGQCKNAC DSYCSPGSPKGPDGOCKNAC DSYCSPGSPKGPDGQCKNAC DSYCSPGSPKGPDGOCKNAC DSYCSPGSPKGPDGQCKNAC DSYCSPGSPKGPDGOCKNAC DSYCSPGSPKGPDGOCKNAC DSYCSPGSPKGPDGQCKNAC DSYCSPGSPKGPDGOCKNAC DSYCSPGSPKGPDGQCKNAC DSYCSPGSPKGPDGOCKNAC DSYCSPGSPRGPDGOCKNAC DSYCSPGSPRGPDGQCKNAC DSYCSPGSPRGPDGOCKNAC DSYCSPGSPRGPDGQCKNAC DSYCSPGSPRGPDGOCKNAC DSYCSPGSPRGPDGOCKNAC DSYCSPGSPRGPDGQCKNAC DSYCSPGSPRGPDGOCKNAC DSYCSPGSPRGPDGQCKNAC DSYCSPGSPRGPDGOCKNAC DSYCSPGSPRGPDGQCKNAC DSYCSPGSPRGPDGQCKNAC DSYCSPGSPRGPDGOCKNAC DSYCSPGSPRGPDGQCKNAC DSYCSPGSPRGPDGOCKNAC DSYCSPGSPRGPDGOCKNAC DSYCSPGSPRGPDGQCKNAC DSYCSPGSPRGPDGOCKNAC DSYCSPGSPRGPDGQCKNAC

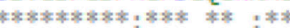

Figure S1. Alignment of the sequences of epitopes 1, 2 and 3 of $\mathrm{Bm} 86$ proteins from distinct isolates to identify the most conserved regions.

This material is avaliable as part of the online article from https://www.scielo.br/rbpv 